\title{
Electrochemical evidence of catalysis of oxygen reduction at the polarized liquid-liquid interface by tetraphenylporphyrin monoacid and diacid
}

\author{
Antonín Trojánek ${ }^{\mathrm{a}}$, Jan Langmaier ${ }^{\mathrm{a}}$, Bin Su ${ }^{\mathrm{b}}$, Hubert H. Girault ${ }^{\mathrm{b}}$, Zdeněk Samec ${ }^{\mathrm{a}, *}$ \\ a J. Heyrovský Institute of Physical Chemistry, v.v.i., Academy of Sciences of the Czech Republic, Dolejškova 3, 18223 Prague 8, Czech Republic \\ ${ }^{\mathrm{b}}$ Laboratoire d'Electrochimie Physique et Analytique, Ecole Polytechnique Fédérale de Lausanne (EPFL), Station 6, CH-1015 Lausanne, Switzerland
}

\section{A R T I C L E I N F O}

\section{Article history:}

Received 24 July 2009

Received in revised form 12 August 2009

Accepted 12 August 2009

Available online 15 August 2009

\section{Keywords:}

Liquid-liquid interface

Oxygen reduction

Decamethylferrocene

Catalysis

Metal-free porphyrin

\begin{abstract}
A B S T R A C T
Cyclic voltammetry is used to study the role of 5,10,15,20-tetraphenyl-21H,23H-porphine $\left(\mathrm{H}_{2} \mathrm{TPP}\right)$ in the reduction of molecular oxygen by decamethylferrocene (DMFc) at the polarized water|1,2-dichloroethane (DCE) interface. It is shown that this rather slow reaction proceeds remarkably faster in the presence of tetraphenylporphyrin monoacid $\left(\mathrm{H}_{3} \mathrm{TPP}^{+}\right)$and diacid $\left(\mathrm{H}_{4} \mathrm{TPP}^{2+}\right)$, which are formed in DCE by the successive transfer of two protons from the acidified aqueous phase. A mechanism is proposed, which includes the formation of adduct between $\mathrm{H}_{3} \mathrm{TPP}^{+}$or $\mathrm{H}_{4} \mathrm{TPP}^{2+}$ and $\mathrm{O}_{2}$ that is followed by electron transfer from DMFc to the adduct leading to the observed production of $\mathrm{DMFc}^{+}$and to the regeneration of $\mathrm{H}_{2} \mathrm{TPP}$ or $\mathrm{H}_{3} \mathrm{TPP}^{+}$, respectively.
\end{abstract}

(c) 2009 Elsevier B.V. All rights reserved.

\section{Introduction}

Biotransformations of molecular oxygen are mediated by enzymes that contain metallic active sites, e.g. bimetallic, heme/Cu catalytic site in cytochrome $c$ oxidase $[1,2]$. Their synthetic analogues have been used to activate molecular oxygen for the $\mathrm{O}_{2}$ reduction to hydrogen peroxide $\left(\mathrm{H}_{2} \mathrm{O}_{2}\right)$ and/or to water in the solution [3], at the solid electrodes [4], or at the polarized liquid-liquid interfaces $[5,6]$. The activation process involves the binding of $\mathrm{O}_{2}$ to the metal center, and the electron delocalization from the metal to $\mathrm{O}_{2}$, which can be viewed like a coordinated superoxide or peroxide anion, i.e., as a Brønsted base $[1,2]$. To the best of our knowledge, the catalysis of $\mathrm{O}_{2}$ reduction by a metal-free porphyrin has not been reported yet.

In this communication we report the catalytic effect of the protonated forms of 5,10,15,20-tetraphenyl-21H,23H-porphine $\left(\mathrm{H}_{2} \mathrm{TPP}\right)$ on the oxygen reduction by decamethylferrocene (DMFc) at the polarized water|1,2-dichloroethane (DCE) interface. Evidence for catalysis comes from ion transfer voltammetry at the water|DCE interface using acidified $\mathrm{Li}_{2} \mathrm{SO}_{4}$ and bis(triphenylphosphoranylidene)ammonium tetrakis(4-chloro-phenyl)borate (BTPPATPBCl) as the supporting electrolytes in water and DCE, respectively. Both water and DCE solutions were saturated with air and contained $0.25 \mathrm{mM} \mathrm{O}_{2}$ [7] and $1.39 \mathrm{mM} \mathrm{O}_{2}$ [8], respectively.

\footnotetext{
* Corresponding author. Tel.: +420 266052017; fax: +420 286582307.

E-mail address: zdenek.samec@jh-inst.cas.cz (Z. Samec).
}

\section{Experimental}

All chemicals were used as received. DMFc (97\%), $\mathrm{H}_{2} \mathrm{TPP}(>99 \%)$, and bis(triphenylphosporanylidene)ammonium chloride (BTPPACl, $>98 \%$ ) were purchased from Sigma-Aldrich. DCE (puriss.p.a.), $\mathrm{Li}_{2} \mathrm{SO}_{4}$ monohydrate (>99\%), tetraethylammonium chloride (TEACl, puriss.p.a., >99\%), and potassium tetrakis(4-chlorophenyl)borate (KTPBCl, Selectophore) were obtained from Fluka. $\mathrm{H}_{2} \mathrm{SO}_{4}$ (Suprapure) was purchased from Merck. BTPPATPBCl was prepared by metathesis of $\mathrm{KTPBCl}$ and $\mathrm{BTPPACl}$ in acetone. The prepared salt was washed with water several times and dried up at $60^{\circ} \mathrm{C}$. Aqueous electrolyte solutions were prepared from highly purified water from a Milli-Q system (Milli-Q Gradient, Millipore).

Voltammetric measurements were carried out at the ambient temperature of $25 \pm 1{ }^{\circ} \mathrm{C}$ in an all-glass four-electrode cell [9], where the flat water|1,2-dichloroethane interface of an area of $0.19 \mathrm{~cm}^{2}$ was formed between mutually saturated solvent phases. The cell can be described by the Scheme 1 , where $x=0-0.05$ and $y=0-0.001, \mathrm{w}$ denotes the aqueous phase, and o denotes the organic solvent phase. Interfacial potential difference $\Delta_{\mathrm{o}}^{\mathrm{w}} \phi=$ $\phi(\mathrm{w})-\phi(\mathrm{o})$ was controlled using a programmable potentiostat (PGSTAT 30, Eco-Chemie, Netherlands), which was equipped with the automatic ohmic drop compensation, and with the frequency response analyzer. The automatic ohmic drop compensation was adjusted to $99 \%$ of the actual ohmic resistance, which was determined by impedance measurements as the real component of the complex impedance at high frequency. Conversion of the voltage applied to the cell to the interfacial potential difference $\Delta_{\mathrm{o}}^{\mathrm{w}} \phi$ was 


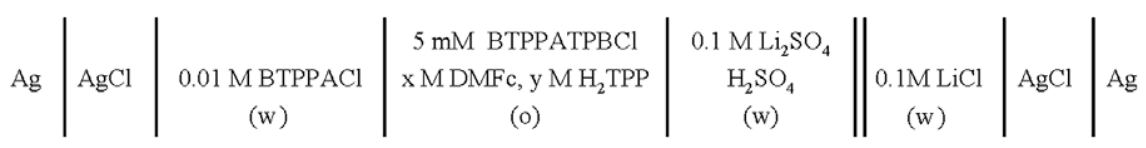

Scheme 1. Composition of the electrochemical cell.

accomplished on the basis of the voltammetric measurements of the ion transfer potential for the $\mathrm{TEA}^{+}$ion $\left(\Delta_{\mathrm{o}}^{\mathrm{w}} \phi_{\mathrm{TEA}}^{0}=0.02 \mathrm{~V}\right)$ in the cell employed [10]. Experiments were performed with either the air-saturated solutions, or the solutions deaerated by argon purging.

\section{Results and discussion}

In the absence of both DMFc and $\mathrm{H}_{2}$ TPP in DCE, recorded cyclic voltammogram (CV) indicates that the interfacial potential difference $\Delta_{\mathrm{o}}^{\mathrm{w}} \phi$ can be varied from -0.45 to $0.45 \mathrm{~V}$ (Fig. 1 , solid blue line). This potential window is determined by the transfer of $\mathrm{Li}^{+}$ and $\mathrm{SO}_{4}^{2-}$ from water to DCE at the positive and negative potential limit, respectively. In the presence of DMFc in the DCE phase, CV exhibits slowly increasing positive current in the range $-0.15 \mathrm{~V}<\Delta_{\mathrm{o}}^{\mathrm{w}} \phi<0.35 \mathrm{~V}$, a steeper rise of the positive current at $\Delta_{\mathrm{o}}^{\mathrm{w}} \phi>0.4 \mathrm{~V}$, and the negative current peak at $\Delta_{\mathrm{o}}^{\mathrm{w}} \phi \sim-0.3 \mathrm{~V}$ on the reverse potential sweep (Fig. 1, solid green line). The positive current can be ascribed to the proton-coupled reduction of $\mathrm{O}_{2}$ with DMFc yielding DMFc ${ }^{+}$, which is detected at $\Delta_{\mathrm{o}}^{\mathrm{w}} \phi \sim-0.3 \mathrm{~V}$ as the current peak of $\mathrm{DMFc}^{+}$transfer from DCE to water [11]. Recently, we have shown that $\mathrm{O}_{2}$ reduction with DMFc in the biphasic acidified water-DCE system leads to generation of $\mathrm{H}_{2} \mathrm{O}_{2}$, when the interfacial potential is set chemically to $\Delta_{\mathrm{o}}^{\mathrm{w}} \phi>0 \mathrm{~V}$ using various salts with a common ion [12].

In the presence of $1 \mathrm{mM} \mathrm{H}_{2}$ TPP in the DCE phase, and in the absence of DMFc, CV exhibits two current peaks at $\Delta_{\mathrm{o}}^{\mathrm{w}} \phi \sim 0.1$ and $0.3 \mathrm{~V}$ (Fig. 1, solid red line), which correspond to the successive transfer of two protons from water to DCE facilitated by the association with $\mathrm{H}_{2}$ TPP and $\mathrm{H}_{3}$ TPP $^{+}$[13],

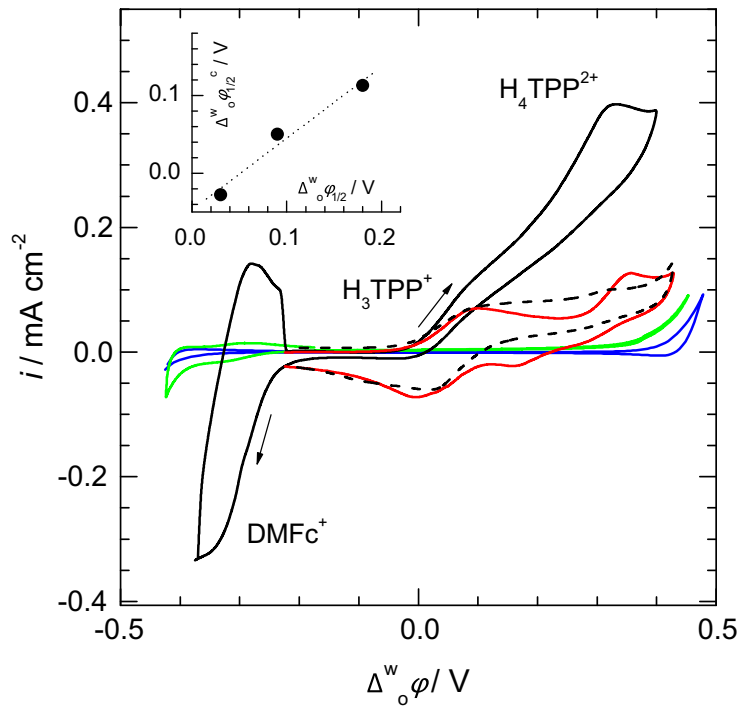

Fig. 1. Cyclic voltammograms $(20 \mathrm{mV} / \mathrm{s})$ for the interface between $0.1 \mathrm{M} \mathrm{Li}_{2} \mathrm{SO}_{4}(\mathrm{pH}$ 2 ) in water and $5 \mathrm{mM} \mathrm{BTPPATPBCl}$ in DCE in the absence (solid blue line) and the presence in DCE of $50 \mathrm{mM}$ DMFc (solid green line), or $1 \mathrm{mM} \mathrm{H}_{2}$ TPP (solid red line), or $1 \mathrm{mM} \mathrm{H}_{2} \mathrm{TPP}+50 \mathrm{mM}$ DMFc (solid black line). Dashed black line: $\mathrm{CV}$ recorded in the presence of $1 \mathrm{mM} \mathrm{H}_{2}$ TPP $+50 \mathrm{mM}$ DMFc with the deaerated solutions. Inset: correlation of the half-wave potential difference $\Delta_{0}^{\mathrm{w}} \phi_{1 / 2}^{c}$ for the first catalytic wave and the half-wave potential difference $\Delta_{o}^{\mathrm{w}} \phi_{1 / 2}$ for the facilitated transfer of the first proton, as inferred from voltammograms measured at $\mathrm{pH} \mathrm{1,2}$ and 3; dashed line was obtained by linear regression.
$\mathrm{H}_{2} \mathrm{TPP}(\mathrm{o})+\mathrm{H}^{+}(\mathrm{w}) \leftrightarrows \mathrm{H}_{3} \mathrm{TPP}^{+}(\mathbf{o})$

$\mathrm{H}_{3} \mathrm{TPP}+(\mathrm{o})+\mathrm{H}^{+}(\mathrm{w}) \leftrightarrows \mathrm{H}_{4} \mathrm{TPP}^{2+}(\mathrm{o})$

Based on the voltammetric data, the dissociation constant of monoacid $\left(\mathrm{H}_{3} \mathrm{TPP}^{+}\right)$and diacid $\left(\mathrm{H}_{4} \mathrm{TPP}^{2+}\right)$ in the presence of tetrakis(penta-fluorophenyl)borate $\left(\mathrm{TFPB}^{-}\right)$have been previously estimated as $K_{\mathrm{a} 1}=1.6 \times 10^{-10}$ and $K_{\mathrm{a} 2}=1 \times 10^{-6}$, respectively [13]. Following the same procedure, somewhat lower values $K_{\mathrm{a} 1}=4.4 \times 10^{-11}$ and $K_{\mathrm{a} 2}=1.8 \times 10^{-7}$ are obtained here in the presence of $\mathrm{TPBCl}^{-}$. In agreement with the spectroscopic and DFT study of the acid-base behavior of $\mathrm{H}_{2}$ TPP in dichloromethane, the occurrence of a large and non-coordinating counter-anion like $\mathrm{TFPB}^{-}$or $\mathrm{TPBCl}^{-}$should result in a stabilization of the monoacid, which is otherwise difficult to detect [14]. A similar voltammetric behavior was reported indicating the successive transfer of two protons facilitated by 5,10,15,20-tetraphenylporphyrinatocobalt(II) (CoTPP), which was obtained from commercial source [5]. However, in a more recent study of catalysis of the oxygen reduction at the polarized liquid-liquid interface by the freshly synthesized CoTPP [6] this result has not be confirmed, and the behavior previously observed [5] has to be ascribed to the free base $\left(\mathrm{H}_{2} \mathrm{TPP}\right)$ present in the commercial sample of CoTPP.

In the presence of both DMFC and $\mathrm{H}_{2}$ TPP in the DCE phase, CV shows a remarkable enhancement of both the positive current in the potential range of the first and second proton transfer step $(0-0.4 \mathrm{~V})$, and the negative peak at $-0.3 \mathrm{~V}$ on the reverse potential sweep (Fig. 1, solid black line) indicating an increased production of DMFc ${ }^{+}$. However, after removing dissolved oxygen from both solutions by argon purging, CV of $\mathrm{H}_{2}$ TPP is recovered (Fig. 1, dashed black line). With the increasing $\mathrm{pH}$ of the aqueous phase, both catalytic waves shift positively by ca. $60 \mathrm{mV} / \mathrm{pH}$. The same shift was reported for the voltammetric peaks of the facilitated proton transfer (Fig. 1, solid red line) [13]. Indeed, the halfwave potential difference $\Delta_{o}^{\mathrm{w}} \phi_{1 / 2}^{c}$ for the first catalytic wave (inflection point on $\mathrm{CV}$ ) exhibits the $1: 1$ correlation with the half-wave potential difference $\Delta_{\mathrm{o}}^{\mathrm{w}} \phi_{1 / 2}$ for the facilitated transfer of the first proton, as inferred from voltammograms measured at $\mathrm{pH} \mathrm{1,2}$ and 3 (inset to Fig. 1). A straightforward mechanistic implication is that the catalytic current is associated with the protonated forms of $\mathrm{H}_{2}$ TPP, the concentration of which at a constant potential decreases with the increasing $\mathrm{pH}$. CV behavior thus points to the regeneration of $\mathrm{H}_{2} \mathrm{TPP}$ and $\mathrm{H}_{3} \mathrm{TPP}^{+}$(or $\mathrm{H}_{2} \mathrm{TPP}$ ) at $\Delta_{\mathrm{o}}^{\mathrm{w}} \phi \sim 0.1$ and $0.3 \mathrm{~V}$, respectively, in two homogeneous electron transfer (ET) reactions in DCE involving DMFc, $\mathrm{O}_{2}$ and $\mathrm{H}_{3} \mathrm{TPP}^{+}$or $\mathrm{H}_{4} \mathrm{TPP}^{2+}$, which follow the first and second $\mathrm{H}^{+}$ion transfer (IT), such as

$$
\begin{aligned}
& \mathrm{H}_{3} \mathrm{TPP}^{+}+\mathrm{O}_{2}+\mathrm{DMFC} \rightarrow \mathrm{H}_{2} \mathrm{TPP}+\mathrm{HO}_{2}^{-}+\mathrm{DMFc}^{+} \\
& \mathrm{H}_{4} \mathrm{TPP}^{2+}+\mathrm{O}_{2}+\mathrm{DMFC} \rightarrow \mathrm{H}_{3} \mathrm{TPP}^{+}+\mathrm{HO}_{2}^{+}+\mathrm{DMFc}^{+}
\end{aligned}
$$

Using the classical electrochemical terminology, each of the two IT-ET sequences above is equivalent to the catalytic EC reaction scheme involving an electron transfer at electrode (E) followed by a chemical reaction $(\mathrm{C})$ regenerating starting material [15-17].

Some insight into the mechanism of the reactions (3) and (4) is provided by examining the effects of the sweep rate and the concentrations of $\mathrm{H}_{2}$ TPP or DMFc. Fig. 2 shows that the height of the first positive peak (wave) at $\Delta_{\mathrm{o}}^{\mathrm{w}} \phi \sim 0.1 \mathrm{~V}$ is independent of the 

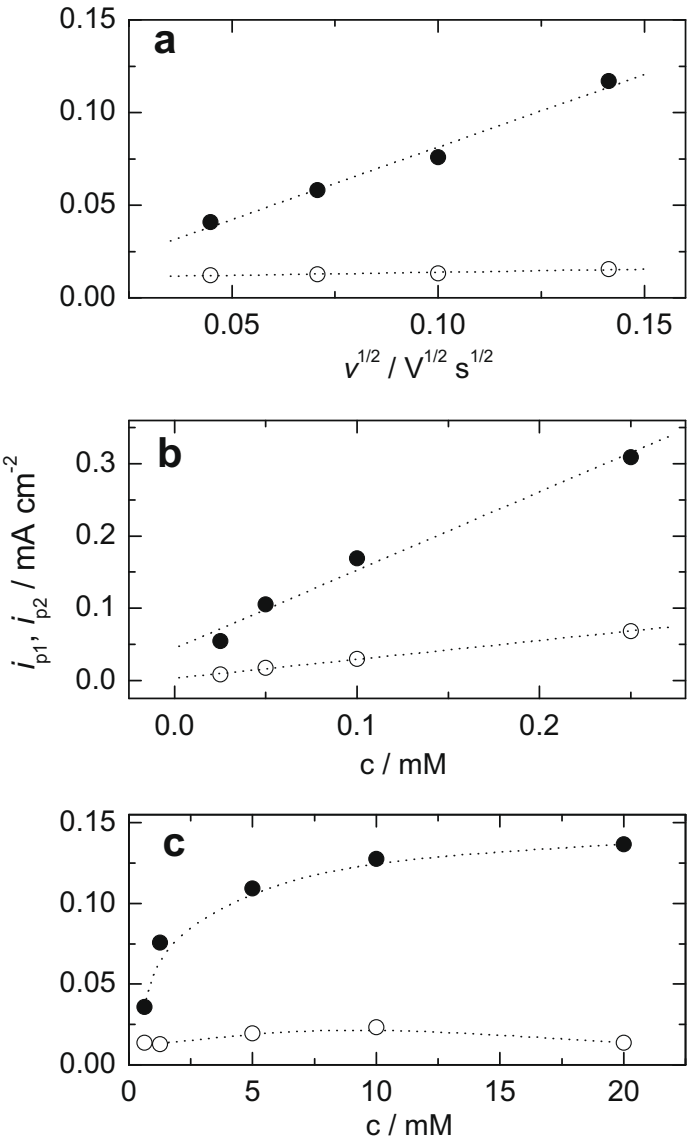

Fig. 2. Effect of (a) sweep rate, (b) concentration of $\mathrm{H}_{2}$ TPP and (c) concentration of DMFc on the height of the first $(O)$ and the second $(\bullet)$ positive voltammetric peak (wave) for the interface between $0.1 \mathrm{M} \mathrm{Li}_{2} \mathrm{SO}_{4}(\mathrm{pH} 2)$ in water and $5 \mathrm{mM}$ BTPPATPBCl in DCE in the presence in DCE of (a) $1.25 \mathrm{mM}$ DMFc and $0.05 \mathrm{mM}$ $\mathrm{H}_{2} \mathrm{TPP}$, (b) $5 \mathrm{mM}$ DMFc, sweep rate $10 \mathrm{mV} / \mathrm{s}$, and (c) $0.05 \mathrm{mM} \mathrm{H}_{2} \mathrm{TPP}$, sweep rate $10 \mathrm{mV} / \mathrm{s}$.

sweep rate (panel a), while it is proportional to the $\mathrm{H}_{2}$ TPP concentration (panel b), and independent of the DMFc concentration (panel c). On the other hand, the height of the second positive peak at $\Delta_{\mathrm{o}}^{\mathrm{w}} \phi \sim 0.3 \mathrm{~V}$ is proportional to both the square root of the sweep rate (panel a) and the $\mathrm{H}_{2}$ TPP concentration (panel b), while it exhibits a nonlinear dependence on the DMFc concentration approaching a constant value at concentrations of DMFc higher than ca. $5 \mathrm{mM}$ (panel c). With the reference to the theory of linear potential sweep [16] and cyclic [17] voltammetry for the catalytic EC reaction scheme, a conclusion can be made that the first IT-ET process is in the pure kinetic region, i.e. the height of the first positive peak (wave) can be considered as a measure of the reaction rate. The effect of the sweep rate suggests that the second IT-ET process is in the pure diffusion or intermediate region.

The effects of the DMFc and $\mathrm{H}_{2}$ TPP concentrations and of the removal of $\mathrm{O}_{2}$ from the system are consistent with the mechanism involving the reversible formation of an adduct between monoacid or diacid and the molecular oxygen that is followed by the irreversible electron transfer from DMFc, e.g. for the reaction (3),

$\mathrm{H}_{3} \mathrm{TPP}^{+}+\mathrm{O}_{2} \underset{k_{-1}}{\stackrel{k_{1}}{\rightleftarrows}}\left\{\mathrm{H}_{3} \mathrm{TPP}^{+}-\mathrm{O}_{2}\right\}$

$\left\{\mathrm{H}_{3} \mathrm{TPP}^{+}-\mathrm{O}_{2}\right\}+\mathrm{DMFC} \stackrel{k_{2}}{\rightarrow} \mathrm{H}_{2} \mathrm{TPP}+\mathrm{HO}_{2}^{+}+\mathrm{DMFc}^{+}$

Our preliminary DFT calculations [18] point to the formation of weak adducts $\left\{\mathrm{H}_{3} \mathrm{TPP}^{+}-\mathrm{O}_{2}\right\}$ and $\left\{\mathrm{H}_{4} \mathrm{TPP}^{2+}-\mathrm{O}_{2}\right\}$, where the molecular oxygen is bound to the protonated nitrogen atoms of two opposite pyrrole rings with the stabilization energy of ca. $0.1 \mathrm{eV}$. By applying the concept of the steady state to the adduct concentration, the rate $r$ of the ET reaction can be described by the equation,

$r=\frac{k_{1} k_{2} c_{\mathrm{DMFc}}^{0} c_{\mathrm{O}_{2}}^{0} c_{\mathrm{H}_{3} \mathrm{TPP}^{+}}}{k_{-1}+k_{2} c_{\mathrm{DMFc}}^{0}}=k^{\prime} c_{\mathrm{O}_{2}}^{0} c_{\mathrm{H}_{3} \mathrm{TPP}^{+}}$

where $k_{1}$ and $k_{-1}$ are the forward and backward rate constants of the adduct formation, respectively, $k_{2}$ is the rate constant of the electron transfer between the adduct and DMFc, $c_{i}$ s are the concentrations of $\mathrm{O}_{2}$, DMFc and $\mathrm{H}_{3} \mathrm{TPP}^{+}$, and $k^{\prime}$ is the pseudo-second order rate constant of the reaction between $\mathrm{O}_{2}$ and $\mathrm{H}_{3} \mathrm{TPP}^{+}$. Obviously, the reaction rate is always proportional to the concentration of $\mathrm{O}_{2}$ and $\mathrm{H}_{3} \mathrm{TPP}^{+}$and, hence, through the Nernst equation to the concentration of $\mathrm{H}_{2}$ TPP, which seems to underlie the observed effects of the oxygen removal (Fig. 1, dashed black line) and of the $\mathrm{H}_{2}$ TPP concentration (Fig. 2, panel b). It is also clear that when the electron transfer from DMFc to the adduct $\left\{\mathrm{H}_{3} \mathrm{TPP}^{+}-\mathrm{O}_{2}\right\}$ is fast enough, so that $k_{2} c^{0}{ }_{\text {DMFc }}>k_{-1}$, the reaction rate becomes independent of the DMFc concentration (Fig. 2, open circles in panel c). The rate constant $k^{\prime}=3.2 \times 10^{3} \mathrm{M}^{-1} \mathrm{~s}^{-1}$ was calculated from the limiting current density of the first kinetic wave $\left(i_{k}=0.023 \mathrm{~mA} \mathrm{~cm}^{-2}\right)$ according to the equation $[16,17]$,

$i_{k}=F c_{\mathrm{H}_{2} \mathrm{TPP}}^{0}\left(D k^{\prime} c_{\mathrm{O}_{2}}^{0}\right)^{1 / 2}$

where $D$ is the diffusion coefficient of $\mathrm{H}_{2}$ TPP. The value $D=5.1 \times 10^{-6} \mathrm{~cm}^{2} \mathrm{~s}^{-1}$ was inferred from the peak current of the first proton transfer facilitated by $\mathrm{H}_{2} \mathrm{TPP}$.

The model can also explain the nonlinear dependence of the second positive peak current on the DMFc concentration (Fig. 2, solid circles in panel c). Essentially, by lowering the DMFc concentration, the second IT-ET process can move from the pure diffusion to the intermediate regime, where the current becomes partly controlled by kinetics of the interfacial reaction.

\section{Conclusions}

Rather slow reduction of molecular oxygen by decamethylferrocene $(\mathrm{DMFC})$ at the polarized water|1,2-dichloroethane (DCE) interface proceeds remarkably faster in the presence of tetraphenylporphyrin monoacid $\left(\mathrm{H}_{3} \mathrm{TPP}^{+}\right)$and diacid $\left(\mathrm{H}_{4} \mathrm{TPP}^{2+}\right)$, which are formed in DCE by the successive transfer of two protons from the acidified aqueous phase. A mechanism is proposed, which includes the formation of adduct between $\mathrm{H}_{3} \mathrm{TPP}^{+}$or $\mathrm{H}_{4} \mathrm{TPP}^{2+}$ and $\mathrm{O}_{2}$ that is followed by electron transfer from DMFc to the adduct leading to the observed production of DMFc ${ }^{+}$and the regeneration of $\mathrm{H}_{2}$ TPP or $\mathrm{H}_{3} \mathrm{TPP}^{+}$, respectively.

\section{Acknowledgement}

This work was supported by Grant Agency of the Czech Republic(Grant No. 203/07/1257), EPFL and European COST Action (D36/ 007/06, OC177).

\section{References}

[1] R.D. Jones, D.A. Summerville, F. Basolo, Chem. Rev. 79 (1979) 139.

[2] J.P. Collman, R. Boulatov, C.J. Sunderland, L. Fu, Chem. Rev. 104 (2004) 561

[3] S. Fukuzumi, K. Okamoto, C.P. Gros, R. Guilard, J. Am. Chem. Soc. 126 (2004) 10441.

[4] E. Song, C. Shi, F.C. Anson, Langmuir 14 (1998) 4315.

[5] A. Trojánek, V. Mareček, H. Jänchenová, Z. Samec, Electrochem. Commun. 9 (2007) 2185.

[6] R.P. Nia, B. Su, F. Li, C.P. Gros, J.-M. Barbe, Z. Samec, H.H. Girault, Chem. Eur. J. 15 (2009) 2335.

[7] D. Pletcher, S.J. Sotiropoulos, J. Chem. Soc. Faraday Trans. 91 (1995) 457.

[8] P. Luhring, A. Schumpe, J. Chem. Eng. 34 (1989) 250. 
[9] V. Mareček, Z. Samec, J. Electroanal. Chem. 185 (1985) 263.

[10] A. Sabela, V. Mareček, Z. Samec, R. Fuoco, Electrochim. Acta 37 (1992) 231

[11] V.J. Cunnane, G. Geblewicz, D.J. Schiffrin, Electrochim. Acta 40 (1995) 3005

[12] B. Su, R.P. Nia, F. Li, M. Hojeij, M. Prudent, C. Corminboeuf, Z. Samec, H.H. Girault, Angew. Chem. Int. Ed. 47 (2008) 4675.

[13] B. Su, F. Li, R.P. Nia, C. Gros, J.-M. Barbe, Z. Samec, H.H. Girault, Chem. Commun. (2008) 5037.
[14] G. De Luca, A. Romeo, L.M. Scolaro, G. Ricciardi, A. Rosa, Inorg. Chem. 46 (2007) 5979.

[15] A.J. Bard, L.R. Faulkner, Electrochemical Methods: Fundamentals and Applications, John Wiley and Sons, New York, 1980. p. 455

[16] J.M. Saveant, E. Vianello, Electrochim. Acta 10 (1965) 905.

[17] R.S. Nicholson, I. Shain, Anal. Chem. 36 (1964) 706

[18] J. Šebera, S. Záliš, A. Trojánek, Z. Samec, in preparation. 